\title{
Hvad skal vi med læreruddannelsen?
}

\section{Om teori- og praksisudfordringer i overgangen mellem læreruddannelse og profession}

\author{
Pia Rose Böwadt, docent, ph.d., Københavns Professionshøjskole, \\ PRB@kp.dk \\ Nana Vaaben, docent, ph.d., Københavns Professionshøjskole, \\ NAVA@kp.dk
}

\begin{abstract}
Resumé
Artiklen undersøger lærerstuderendes og nye læreres identitetsarbejde i tilblivelsen som lærere samt hvilke teori/praksis-forståelser, der opstår i processen. Under uddannelsen motiveres de studerende af en forestilling om den gode lærer, og de beskytter denne forestilling gennem afstandtagen og selvansvarliggørelse. Som færdiguddannede i en presset hverdag med handletvang vanskeliggøres identitetsarbejdet dog, når de oplever at måtte gå på kompromis med netop denne idé. De nye lærere efterspørger derfor redskaber og en mere virkelighedstro læreruddannelse. Artiklen viser, at de lærerstuderende og nye lærere abonnerer på en professionsforståelse, der handler om viljen til at påtage sig forpligtelser, men ikke på en professionsforståelse, der indbefatter udvikling af teori og brug af professionsfagligt sprog. De udtrykker primært en dikotomisk teori/praksis-forståelse med en forestilling om, at "virkeligheden" findes ude på skolerne. Artiklen diskuterer forholdet mellem teori og praksis og foreslår en mindre dikotomisk forståelse af og balance mellem praksisnærhed og praksisfjernhed i såvel læreruddannelse som folkeskole.
\end{abstract}

Nøgleord: læreruddannelse, professionsidentitet, skole, teori/praksis-forståelser

\begin{abstract}
The article explores student teachers' and new teachers' identity-work and implied theory/practice understandings in the process of becoming teachers. During their education students are motivated by an idea of the good teacher and seek to protect this idea through distancing and self-responsibilization. Having finished education, identity-work is challenged by their discovery of having to compromise such ideas in a demanding and intensified job, and accordingly the new teachers request tools and realistic education. The article shows how student teachers and new teachers express professionalism if understood as a question of wanting to take on responsibilities, but not if understood as a question of developing theory and having a professional language. Students and new teachers primarily operate with a dichotomized theory/practice understanding and think reality equals schools. The article suggests a less dichotomized understanding concerned with connecting theory and practice and striking a balance between being close to and distanced from practice - in schools as well as in teacher education.
\end{abstract}

Keywords: teacher education, professional identity, schools, theory and practice 
I en pressemeddelelse fra Uddannelses- og Forskningsministeriet d. 27. november 2020 lyder det, at der skal være "styrket praktik og praksisarbejde" i den nye læreruddannelse. De lærerstuderende "skal klædes bedre på til at træde ud i virkeligheden" (Uddannelses- og Forskningsministeriet, 2020). Læreruddannelsen er og har længe været genstand for debat og kritik, og et tilbagevendende tema er vægtningen af teori og praksis. I en evaluering fra 1989 hedder det fx: "I mange tilfælde har seminariets lærere ikke gjort andet indtryk på de studerende end at være nogle rare mennesker, der sad og snakkede i lang tid om noget ikke vedkommende stof"' (Jacobsen, 1989, s. 28). Evalueringen efterlader læseren med indtrykket af, at det, man lærte på seminariet i 1980'erne, ikke var videre nyttigt i forhold til den kommende lærergerning. Der efterlyses også en større vægtlægning af praktikken, bedre praktiklærere og en "realistisk jobforberedelse" (Jacobsen, 1989, s. 124). Evalueringen er over 30 år gammel, så hvordan ser det ud, hvis man i dag spørger de lærerstuderende og de nye lærere om, hvad de synes om læreruddannelsen? Oplever de, at den nuværende læreruddannelse klæder dem på til jobbet som folkeskolelærer? Og hvad tænker de om forholdet mellem teori og praksis i læreruddannelsen?

I denne artikel vil vi forsøge at besvare disse spørgsmål på baggrund af en række undersøgelser, vi har foretaget blandt både lærerstuderende og færdiguddannede lærere i Danmark gennem de seneste fem år. Overordnet set tegner både lærerstuderende og nyuddannede lærere et billede af læreruddannelsen, der på flere måder ligner det fra 1989. De mener, at læreruddannelsen er for teoretisk og virkelighedsfjern, og de ønsker sig mere praktik og mere praksisnær undervisning (Böwadt \& Vaaben, 2021; Böwadt et al., 2017; Pedersen et al., 2019). Derudover peger empirien også på, at mange lærerstuderende allerede inden studiet har en klar idé om, hvordan en god lærer er. De har på baggrund af deres barndomserfaringer med egne grundskolelærere fået et indtryk af, hvad lærerprofessionen er og kan, og dette indtryk er centralt for både deres motivation og identifikation gennem uddannelsen (Böwadt et al., 2017). Men når de lærerstuderende allerede inden påbegyndt uddannelse har så stærk en identifikation og familiaritet (Lindhart, 2007; Bjerre, 2016) med lærerprofessionen, og når de undervejs og efter uddannelsen i den grad efterlyser mere praktik, melder spørgsmålet sig: Hvad skal vi med læreruddannelsen?

I det følgende skal det i første omgang omhandle de studerendes identitetsdannelse som lærer og deres motivation for lærerjobbet. Dernæst kigger vi nærmere på de studerendes og de nye læreres syn på læreruddannelsen, i 
særdeleshed deres syn på forholdet mellem teori og praksis. Det fører videre til en diskussion af begreberne praksisnærhed og praksisfjernhed og en diskussion af, hvorfor studerende og nye lærere kan have svært ved at se brugbarheden af teori i forhold til lærergerningen. I den afsluttende diskussion argumenterer vi for, at netop $\mathrm{i}$ en tid, hvor folkeskolen er og har været under et massivt pres og gennem mange forandringer, og hvor mange lærere har forladt folkeskolen eller oplevet at måtte slække på deres idealer om lærergerningen, er løsningen ikke udelukkende mere praktik. Der er brug for en læreruddannelse, der klæder de studerende på til at være med til at udvikle folkeskolen gennem kritisk refleksion og professionel dømmekraft. Vores egne undersøgelser vil løbende blive holdt op i mod anden forskning om læreruddannelse, lærerprofession og professionsidentitet.

\section{Empiri og metode}

Artiklen baserer sig på undersøgelser af både lærere og lærerstuderende, som vi har foretaget over de sidste fem år. Vi har både undersøgt lærere, der har valgt at forlade folkeskolen, lærere, der stadig er i folkeskolen, lærerstuderende på henholdsvis første og syvende semester samt nye folkeskolelærere. Fælles for alle undersøgelser er, at der er tale om, hvad vi betegner "kvalitative elektroniske spørgeundersøgelser". Konkret trækker vi i større eller mindre omfang på følgende undersøgelser:

Hvorfor stopper lærerne i folkeskolen? En undersøgelse blandt lærere, der var stoppet i en folkeskole mellem 2013 og 2016. Undersøgelsen havde 405 respondenter (Pedersen, R., Böwadt, P. R., \& Vaaben, N., 2016)

"Først og fremmest elsker jeg at arbejde med børn" - om studerendes valg af lærerlivet. En undersøgelse blandt helt nye 1 . semesterstuderende på læreruddannelsen på daværende UCC. Undersøgelsen havde 477 respondenter (Böwadt, P. R., Pedersen, R. \& Vaaben, N., 2017) 
Når verdens bedste job bliver for hårdt - en undersøgelse af, hvordan lærere har det i folkeskolen. Undersøgelsen havde 1232 respondenter (Böwadt, P. R., Pedersen, R., \& Vaaben, N., 2019a)

På tærsklen til at blive lærer - studerendes overvejelser om deres kommende arbejdsliv. En undersøgelse blandt 7. semesterstuderende på læreruddannelsen på Københavns Professionshøjskole. Undersøgelsen havde 298 respondenter (Böwadt, P. R., Pedersen, R., \& Vaaben, N, 2019b)

Ny i professionen - de første år som lærer. En undersøgelse blandt nyuddannede folkeskolelærere med mindre end 4 års erfaring. Undersøgelsen havde 105 respondenter (Böwadt, P. R., \& Vaaben, N., 2021).

I denne artikel trækkes der hovedsagelig på de to undersøgelser blandt lærerstuderende på henholdsvis første og syvende semester samt på undersøgelsen blandt nye lærere. De øvrige undersøgelser bruges perspektiverende. I alle undersøgelserne er der blevet stillet få åbne spørgsmål, som er blevet distribueret elektronisk og besvaret med fritekst. Vi har fx spurgt: "Hvorfor vil du gerne være lærer?" eller "Hvordan er det for dig at være ny lærer i folkeskolen?" Formålet med at spørge på denne måde er at give lærerne og de lærerstuderende mulighed for at formulere sig med egne ord og at skrive om de emner, de synes er vigtige, frem for at vælge mellem prædefinerede svar. Et andet fællestræk ved undersøgelserne er, at vi har modtaget mange svar - flere, end man normalt arbejder med i kvalitative undersøgelser. Dette ændrer dog ikke på, at der er tale om kvalitative undersøgelser, og vi benytter derfor også kvalitative analysetilgange.

De to undersøgelser blandt studerende er gennemført ved at uddele link til spørgsmålene til alle studerende på de pågældende årgange. Denne distributionsmetode kunne imidlertid ikke bruges til at få fat i færdiguddannede lærere, som vi i stedet har annonceret efter på Folkeskolen.dk, hvorefter annoncerne er blevet delt på sociale medier. Den primære interesse har været at analysere svarene kvalitativt ved betragte svarene som elementer i de studerendes og lærernes identitetsarbejde.

Ud fra et narrativt perspektiv er identitetsarbejde at forstå som de måder, hvorpå mennesker uophørligt og i samspil med andre konstruerer fortæl- 
linger om, hvem de er, og hvad de gør (Driver, 2009; Humle, 2014; Humle \& Frandsen, 2017). Identitet opfatter vi derfor som noget, der altid er under tilblivelse, og denne tilblivelsesproces kræver identitetsarbejde. Dette arbejde handler om løbende at forstå og skabe mening i, hvem man er, og hvem man er ved at blive til som individ og gruppe.

Inden for studier af lærerprofession og læreruddannelse har der gennem de senere år været en interesse for at undersøge, hvorledes læreridentitet bliver til gennem narrativ praksis (Dahl, 2020; Vaaben \& Bjerg, 2019). I narrativt identitetsarbejde handler det altså om at konstruere forståelser af, hvem man er, og hvem man er ved at blive til; men i disse fortællinger opstår samtidig også konstruktioner af andre mennesker, steder og praksisser.

Betragtes svarene i et narrativt perspektiv, kan vi bl.a. se, hvordan andre mennesker, fx ældre lærere, kan optræde som rollemodeller eller som "gamle brokkehoveder", ligesom forskellige steder og institutioner i fortællingerne kan beskrives som henholdsvis "virkelige" og "uvirkelige", og forholdet mellem teori og praksis ligeledes konstrueres på forskellige måder. I analyseprocessen er svarene kodet i Nvivo, som er et program til kodning af store mængder kvalitative data. På den måde har vi kunnet finde mønstre og har bl.a. kunnet se, hvilke narrativer der går igen i rigtig mange svar og evt. på tværs af de forskellige undersøgelser. Det er primært dem, der fokuseres på i det følgende.

\section{Lærer - det er lige mig!}

Når man spørger lærerstuderende, hvorfor de gerne vil være lærere, er svaret overordnet set meget klart. Det handler primært om de sociale relationer. De vil være lærere, fordi de vil "arbejde med mennesker" eller "gøre en forskel". De er sjældent motiveret af en faglig optagethed. Det er ikke overraskende. Både danske og internationale undersøgelser bekræfter, at relationen til børnene er den primære drivkraft for både lærerstuderende og lærere (Vidø \& Marcussen, 2002; Moos, 2011; Mintrop \& Ordenes, 2017; Bayer, 2017). I undersøgelsen af studerende på første semester blev de studerende spurgt, to uger efter de var begyndt på studiet. Hensigten med det var, at de på det tidspunkt endnu ikke var blevet præget af uddannelsesinstitutionen. De studerende blev bl.a. spurgt om, hvorfor de gerne ville være lærere, og hvordan de havde fundet ud af, at de skulle være lærere. Svarene var interessante, fordi det blev meget tydeligt, at de studerende, allerede inden de er kommet i gang med uddannelsen, har en klar opfattelse af, hvad en god lærer er, og 
at denne idé om den gode lærer er en væsentlig grund til, at de overhovedet valgte at søge ind på uddannelsen. Det ses fx i dette svar:

\begin{abstract}
"Jeg vil gerne være lærer, fordi jeg havde en lærer i folkeskolen, og hun var bare meget mere end en lærer. Hun var som en rollemodel, og en person, man altid kunne komme til. Derfor kunne jeg godt tænke mig at være lærer, jeg kunne godt tænke mig at være den person, der skal hjelpe andre unge videre, ikke kun uddannelsesmæssigt, men også personligt, og vare med til at forme dem. Jeg blev klar over det, dengang jeg gik i folkeskole. Jeg kan godt lide at have med mennesker at gøre, og da min lærer var sådan over for mig, gik det op for mig, at sådan en person ville jeg gerne være. En person, der var nogle der så op til." (Lærerstuderende, første semester 2017)
\end{abstract}

Som citatet illustrerer, forestiller de nye studerende sig, at en lærer er mere end blot en funktion eller et job. Det er et gennemgående træk i mange svar. De studerende ser frem til et virke som lærer, hvor relationen til eleverne er i fokus, hvor man er på arbejde med hele sin person, og hvor man ikke bare underviser børn og unge i et fag, men gør en vigtig forskel i deres liv. Personen, eller forestillingen om, at relationen til eleverne skal være personlig, spiller med andre ord en stor rolle for, at de studerende overhovedet har meldt sig ind på uddannelsen (Böwadt et al., 2021; Bayer, 2017). Tilblivelsen af en professionsidentitet foregår altså ikke udelukkende på uddannelsen, men ser ud til at begynde længe inden. Derudover tyder det på, at de studerende har en forestilling om en "ideel" lærer, og netop den forestilling motiverer dem. Stort set ingen har svaret, at de vil være lærer på grund af løn, status, vilkår eller interesse for et bestemt fag (om lærerstuderendes motivation se også Dorf, 2018, s. 250). Tværtimod distancerer mange af de studerende sig fra sådanne forhold, og de distancerer sig også fra "ældre lærere", som de mener er nogle "brokkehoveder", der "taler folkeskolen ned" (Böwadt et al., 2020, s. 96). Drivkraften og motivationen retter sig entydigt mod en særlig slags relation til deres fremtidige elever, og mange af de nye lærerstuderende er derfor indstillet på at "tage hele pakken med". Forestillingen synes at være, at hvis de bare brænder nok for det, skal de nok klare, hvad end der måtte komme. Der er således tale om en form for selvansvarliggørelse, hvor de studerende pålægger sig selv ansvaret for at lykkes som lærere og for at kunne leve op til det lærerideal, der motiverer dem (Böwadt 
et al., 2020; 2021; for mere om selvansvarliggørelse se også Willig, 2013; Rose, 1999).

Motivationen og drivkraften er stort set den samme hos de studerende på syvende semester; dog fylder skolens fag mere i svarene, og de studerende begynder at identificere sig som fx matematik- eller dansklærere (Böwadt et al., 2019b, s. 57). I forhold til dannelsen af en professionsidentitet er det dog vigtigt at understrege, at de studerende stadig identificerer sig med forestillingen om en lærer, der er mere end sit job, og som betyder andet og mere for sine elever end blot at undervise dem i bestemte fag. Det ses fx i dette citat:

\section{"Det er en god kombination af at arbejde med børn og samtidig arbejde inden for nogle fagfaglige områder, der interesserer mig (litteratur, politik, musik f.eks.). At kunne give sin passion og glæde ved fag videre og naturligvis også forhåbentlig kunne gøre en forskel i elevernes liv - hjælpe dem til at finde den rette vej, gøre dem opmærksomme på deres talenter og bidrage til, at de fär det bedste ud af deres skolegang." (Lærerstuderende, syvende semester 2019)}

De studerende på syvende semester er også begyndt at forholde sig til, om læreruddannelsen og forholdene på skolerne muliggør, at de kan blive den lærer, de gerne vil blive. De bliver blandt andet spurgt om, hvilken type skole de gerne vil arbejde på. Her er det interessant, at de, der vil søge arbejde på en folkeskole, giver ideologiske begrundelser herfor, mens de, der vil søge arbejde på en fri- eller privatskole, argumenterer med arbejdsvilkår. De mener, at man vil få mere frihed og tid til eleverne der. De har så at sige stadig en klar idé om, hvad det er for en lærer, de gerne vil blive til, og de overvejer også forskellige strategier for at undgå de værste arbejdsvilkår i folkeskolen, som evt. vil kunne forhindre dem deri. Flere skriver, at de vil vælge en kommune og en skole med gode forhold og med en leder, der "bakker op". På den måde pålægger også de syvende semester-studerende sig selv ansvaret for at kunne finde løsninger og blive den lærer, de gerne vil være efter endt uddannelse - om end på en måde, hvor de i højere grad er opmærksomme på skolernes organisatoriske indretning. Nu handler det ikke blot om at brænde for det, men om at navigere og vælge den rette skole.

En stor del af de studerende påpeger i deres svar, at læreruddannelsen er virkelighedsfjern og for teoretisk. Interessant i den forbindelse er det, at mens skolerne beskrives som "virkelige" og som et vilkår, man ikke kan lave om på, har de studerende en opfattelse af, at læreruddannelsen er uvirkelig 
og både kan og bør ændres, så den kommer tættere på "virkeligheden". Det vender vi tilbage til.

Vi har også gennemført en undersøgelse blandt nye lærere, der har arbejdet mindre end fire år i folkeskolen. Undersøgelsen kan give et indblik i, hvad der sker med læreridentiteten efter endt uddannelse. Når man ser på de nye læreres identitetsarbejde, er det interessant, at flere af dem beretter om det tab og den smerte, der er forbundet med at måtte indse, at det lærerideal, der har motiveret dem, fået dem til at søge ind på læreruddannelsen og fået dem igennem studiet, er svært at indfri i dagens folkeskole. Flere af de nyuddannede lærere skriver således om, hvor svært det er at erkende, at man er nødt til at gå på kompromis med selve kernen i det, man har valgt uddannelse efter og identificerer sig med. Frustrationerne over dette ses fx i følgende citat:

"Det sværeste har helt klart været at nærmest blive tounget til at sænke sine ambitioner for ikke at gå ned. Jeg hører det alle steder, fra ledelsen og fra kollegaer. 'Du bliver simpelthen nødt til at sænke dine ambitioner, ellers går du ned'. Det er rigtigt, men utrolig frustrerende, at den bedste løsning for at klare jobbet er at sænke sine ambitioner. Sammen med min studiegruppe skrev jeg bachelor om, hvordan man laver god og vedkommende undervisning $i$ historie. Vores bachelor vandt tredjepladsen som den bedste bachelor i 2018. Efter det var jeg totalt klar på at komme ud og lave god og spændende undervisning. Men den gejst er langsomt forsvundet. Fordi der er ikke særlig meget tid til fordybelse. Det er det sværeste for mig." (Ny folkeskolelærer 2021)

På den måde kan man på tværs af de tre undersøgelser se et interessant samspil mellem idealer og "virkelighed". De lærerstuderende og de nye lærere er enige om idealerne; de er enige om, hvad en god lærer er, og de er enige om, at sådan en lærer vil de gerne være. En enighed, de i øvrigt deler både med de erfarne lærere ude i folkeskolerne og de forhenværende folkeskolelærere (Pedersen et al., 2016; Böwadt et al., 2019b; 2020). De er også langt hen ad vejen enige om, at folkeskolen ideelt set er en vigtig samfundsinstitution. Igen er der tale om et ideal, som kan genkendes hos både nuværende folkeskolelærere og lærere, som har forladt folkeskolen (Pedersen et al., 2016; Böwadt et al., 2019b; 2020). Det ser dog ud til, at forholdet til idealer og "virkelighed" ændres gennem uddannelsen og livet som folkeskolelærer. Noget tyder på, at de studerende i begyndelsen af uddannelsen holder fast i idealerne og 
regner med at kunne indfri dem og blive til den lærer, de drømmer om, hvis de insisterer på at holde økonomiske og politiske forhold - samt ældre lærere, der brokker sig - på behørig afstand. I slutningen af uddannelsen begynder de at opfatte skolerne som fremtidige arbejdspladser, og de forbereder sig på at skulle navigere og finde en god skole, eventuelt at måtte vælge en fri- eller privatskole, selvom de i princippet "går ind for folkeskolen". De er stadig indstillet på selv at have ansvaret for tilblivelsesprocessen og for at lykkes og indfri idealerne. Når de begynder at arbejde som lærere, opdager nogle af dem dog, at det er svært at indfri idealerne, hvilket medfører en form for identitetstab. At skulle gå på kompromis med eller give afkald på netop de idealer, som er afgørende for deres professionsidentitet, og som har båret dem gennem uddannelsen, er en vanskelig proces, som de oplever at stå alene med. Spørgsmålet er, hvad henholdsvis læreruddannelsen og folkeskolerne stiller op med denne situation. På den ene side insisterer de studerende under uddannelsen på at holde fast $\mathrm{i}$ idealerne, vælge "med hjertet" og lukke ørerne for alt, hvad ældre lærere, undervisere eller andre måtte have at sige om, hvordan skolerne "i virkeligheden er". På den anden side er både studerende og nyuddannede lærere enige om, at de på uddannelsen skulle have lært meget mere om, hvordan det "i virkeligheden er", i stedet for at blive præsenteret for, hvordan undervisning, lærere og skoler ideelt set kunne være.

Som det er fremgået, er det idealet om den gode lærer, der motiver mange af de studerende. Hvordan den gode lærer er, har de studerende en klar forestilling om, allerede inden de begynder på uddannelsen. Læreruddannelsen adskiller sig her netop fra andre professionsuddannelser ved, at de studerende tror, de kender professionen på forhånd (Lindhart, 2007). Det kan ifølge nogle forskere være problematisk, fordi det kan resultere i det, man kalder "premature closure" (Bjerre, 2016). Læreruddannelsen står dermed ofte med den udfordring, at den på den ene side skal bryde de studerendes forståelse af professionen ned - eller i hvert fald kvalificere og udvide den. På den anden side skal læreruddannelsen passe på, at de ikke gør det på en måde, der går ud over de studerendes motivation, der netop er bundet op på den forestilling om den gode lærer, som de havde i forvejen. Det er særligt udfordrende, fordi de studerende ofte finder læreruddannelsen virkelighedsfjern, hvilket vi skal se nærmere på i næste afsnit. 


\section{Studerendes og nye læreres teori/praksiskonstruktioner}

Ifølge Alexander von Oettingen opstår en profession, når praksis bliver så kompleks, at man får brug for teoretisk refleksion (von Oettingen, 2007, s. 18). Spændingen mellem teori og praksis ligger derfor implicit i lærerprofessionen. Den kan ikke fjernes eller overvindes, men er et vilkår. Det kan dog være problematisk, hvis afstanden mellem teori og praksis opleves som for stor af de lærerstuderende. Det kan bl.a. medføre frafald (Krarup, 2017).

I det følgende undersøges de nye læreres syn på læreruddannelsen; i særdeleshed undersøger vi, hvordan forholdet mellem teori og praksis kommer til udtryk i deres svar.

Når man spørger de lærerstuderende og de nye lærere om, hvad de kunne bruge, og hvad de mangler i læreruddannelsen, er svaret ikke overraskende, at de ønsker sig mere praktik og mere praksisnær undervisning. De efterlyser også konkrete redskaber og værktøjskasser. Den efterspørgsel er på ingen måde ny (se fx Jacobsen, 1989; Johansen, 2017; Ekspertgruppen, 2018), og den er ikke enestående for danske lærerstuderende. Undersøgelser i fx Norge tegner det samme billede (Hovdenak \& Wiese, 2017). De studerende og de nye lærere er på ingen måde ene om det ønske. Det er påfaldende, at de interessenter, der i andre sammenhænge er dybt uenige om udformningen af såvel læreruddannelse som folkeskolen, her tilsyneladende er enige. Både Danmarks Lærerforening, Kommunernes Landskreds, Skolelederforeningen, Lærerstuderendes Landskreds og uddannelses- og forskningsministeren ønsker en mere praksisnær læreruddannelse. Efterspørgslen efter mere praksis er med andre ord meget stor.

Overordnet set er mange studerende og nye lærere utilfredse med forholdet mellem teori og praksis; men de ser ikke ens på forholdet. Vi er forenklet sagt stødt på tre forskellige typer af teori/praksiskonstruktioner, som centrerer sig om henholdsvis opposition, simulation og refleksion.

Den første teori/praksiskonstruktion, vi støder på, opstiller teori og praksis som to poler, der er i opposition til hinanden. I disse svar efterspørges der mere praksis, hvilket som oftest sidestilles med mere praktik og med tilsvarende mindre teori, eftersom de to ses som gensidigt udelukkende. Det ses tydeligt i dette svar fra en studerende på syvende semester, der ligefrem foreslår, at visse dele af uddannelsen byttes ud med praktik:

\section{"Jeg ville gerne ud og have endnu mere praksisviden og erfaring. Jeg mener slet ikke, der er nok, og mange af de ting, vi laver på studiet,}




\section{kunne sagtens blive byttet ud med praktik. Jeg tror, det er godt givet ud $i$ sidste ende, og at man på den måde står med den kerne af mennesker tilbage, der virkelig brænder for det her felt. Teori kan alle komme igen- nem!" (Lærerstuderende, syvende semester 2019)}

I dette og andre svar beskrives forholdet mellem teori og praksis som to gensidigt udelukkende måder at opnå viden på, som foregår gennem forskellige typer aktiviteter, der foregår på forskellige tidspunkter. I svarene sidestilles praksis typisk med praktikperioderne, og teori sidestilles med at læse bøger og gå til undervisning. Denne konstruktion af teori og praksis som noget, der er i opposition til hinanden, finder vi i en del af svarene fra både studerende og nye lærere.

Men der er også andre måder at forstå forholdet på. En anden teori/praksiskonstruktion, som går igen, centrerer sig om imitation. En del studerende og nye lærere kritiserer læreruddannelsen for ikke at ligne praksis godt nok. I nogle tilfælde er det igen det teoretiske, der står for skud og beskrives som "misvisende" eller "for langt fra virkeligheden". "Børn gør jo ikke, som der står i bøgerne", skriver en ny lærer; en anden pointerer, at "på læreruddannelsen var der alt muligt, og der var redskaber til næsten alle typer sport - det er der jo slet ikke på de forskellige folkeskoler". I andre svar ser vi, at også praktikperioderne vurderes efter, hvor godt de ligner virkeligheden. En ny lærer siger: "Praktikken er jo der, at man er kommet tættest på virkeligheden, og derfor der, man har lært mest. Så jeg kunne godt have ønsket en længere praktik", og en anden fortsætter i samme spor: "Praktik er godt, det ville være bedre, hvis den mindede mere om virkeligheden". Den sidste kommentar handler om, at man i en praktikperiode har færre timer og forpligtelser end som færdiguddannet, og igen er anken, at uddannelsen fejler ved ikke at ligne det job, man kommer ud i som lærer, godt nok. I nedenstående svar er ønsket om imitation også tydeligt. Svaret handler om, hvad man som ny lærer kunne have ønsket sig af læreruddannelsen:

\footnotetext{
"Praksisnær undervisning - forløb, vi kunne tage direkte i lommen og med ud at bruge. Kunne godt have ønsket et billede af, hoor kaotisk dagligdagen kan være. Undervisningen bar ofte præg af at være ret utopisk. Vi brugte et år på at lave undervisning/lektionsplan. Jeg har ikke lavet en siden." (Ny lærer 2020).
} 
En tredje form for teori/praksiskonstruktion fokuserer på refleksion. Her er tanken, at teori og praksis skal indgå i et samspil, og at teorien skal kunne bruges til at reflektere og tænke over egen praksis med. Den forståelse af praksis er dog ikke særlig udbredt i svarene. Eksempler på den ses i disse to svar fra nye lærere:

\section{"Jeg synes, at det har været de meget korte praktikker. Det er her, man giorde sig nogle reelle erfaringer med, hoad jobbet egentlig handler om. Derudover har det været didaktik og pædagogik, som har lært mig at tænke og reflektere over mig selv som lærer. Det bruger jeg stadig meget i dag." (Ny lærer 2020)}

En anden svarer:

\section{"Mere praktik. Men samtidig synes jeg også der er en pointe $i$, at lerer- uddannelsen er så teoretisk, som den er. Jeg synes, jeg kan trække på rigtig mange ting fra uddannelsen!" (Ny lærer 2020)}

Som det er fremgået, opererer mange lærerstuderende og nye lærere med teori/praksiskonstruktioner, der centrerer sig om enten opposition eller imitation - og i begge disse teori/praksiskonstruktioner gives forrang til praksis. Enten fordi teori forstået som "det, man laver på uddannelsen" skal erstattes af praktik, eller også fordi teorien i højere grad skal ligne praksis og indrettes efter praksis - som altså af de studerende og nye lærere sidestilles med det, man "i virkeligheden" laver som lærer ude på folkeskolerne. Kun forholdsvis få opfatter teori som noget, der kan bruges til at reflektere over egen praksis, sådan som det fremgik i de sidste to citater.

For det første ser det altså ud til, at de studerende og nye lærere frustreres over, at de idealer, de har higet efter og støttet sig til i deres professionelle tilblivelsesproces under uddannelsen, ser ud til at være langt fra de forventninger, de møder som færdiguddannede. Det medfører en form for identitetskrise, hvor de bliver i tvivl om, hvem de er ved at "blive til". For det andet ser det ud til, at i takt med at de studerende opdager dette misforhold, så efterspørger de en mere "virkelighedstro" læreruddannelse, der i højere grad består af praktik eller ligner praksis forstået som en "rigtig skolevirkelighed". På den baggrund kunne man lidt provokerende spørge: Er der så overhovedet behov for en læreruddannelse? Hvis pointen er, at kommende lærere skal lære at begå sig i den virkelighed, der til en hver tid er at finde 
ude på folkeskolerne, hvorfor så ikke bare sende dem direkte derud og gøre sig nogle erfaringer? Som det vil fremgå af de følgende afsnit og den afsluttende diskussion, mener vi ikke, at løsningen er så enkel.

Vores undersøgelse ligger i tråd med mange andre undersøgelser af lærerstuderendes og nye læreres syn på teori- og praksisforholdet (se fx Dorf, 2018, s. 255). Her påpeges det også, at studerende oplever at uddanne sig " $i$ to forskellige verdener". Hans Dorf gør i den forbindelse opmærksom på, at lærerstuderende ikke nødvendigvis forberedes på, at der kan være frustration forbundet med at inddrage teori i refleksionen over egen praksis.

Det er som nævnt tidligere et spændingsforhold, som er indbygget i lærerprofessionen og dermed også i læreruddannelsen. Der har været mange forsøg på at opliste, hvor mange forskellige forståelser af forholdet mellem teori og praksis der eksisterer (se fx Dorf, 2018, s. 254; Nielsen, 2014, s. 39; Jorgensen, 2005; Carlsen \& von Oettingen, 2020, s. 6). De forskellige modeller skal ikke gennemgås her, men det rejser et spørgsmål om, hvorfor en stor del af de studerende og nye lærere har et relativt enkelt og forsimplet syn på forholdet. Det peger på, at der er noget, som læreruddannelsen ikke er lykkedes med, og som læreruddannelsen med fordel kan adressere bedre. Der er også undersøgelser, der peger på nødvendigheden af at udvikle et fælles fagsprog for læreruddannere, praktiklærere og lærerstuderende. Samt undersøgelser, der peger på, at nogle former for læreruddannelse, herunder den danske, er præget af et hverdagssprog (Afdal, 2012; Dorf, 2018; Jacobsen \& Komischke-Konnerup, 2019).

Som nævnt lyder der fra mange sider et ønske om en praksisnær læreruddannelse. Adskillige forskere har dog kritiseret en for ensidig fokusering på praksisnærhed og betonet vigtigheden af praksisfjernhed og distance. Overordnet er indvendingen, at man har brug for distance til praksis (von Oettingen, 2006; Fink, 2019; Bjerre, 2016). Ifølge disse forskere skal man som lærer kunne reflektere over egen praksis, og det fordrer en teoretisk distance. Praktikeren derimod arbejder intuitivt, og der ligger altid en række implicitte normer i praksis, som man ofte bliver blind overfor. Det er for os at se en vigtig grund til, at de lærerstuderende - deres stærke ønsker til trods - ikke kan nøjes med erfaringsbaseret viden og "mesterlære". Hvis der skal udvikles kundskab, er det derfor nødvendigt at kunne problematisere praksis ( $\mathrm{f} x$ Andersen, 2020, s. 62). Filosoffen Hans Fink påpeger, at en uddannelses- og forskningsinstitution har brug for praksisfjernhed. Forskning skal naturligvis være nyttig og gavne klienten, borgeren eller eleven, men forskning kræver frihed og en relativ uafhængighed af praksis. Fink nævner i forlæn- 
gelse af det, at det er forståeligt, at politikere stiller krav til forsknings- og uddannelsesinstitutioner om anvendelighed. Men pointen er, at det ikke er gjort med at sige mere praktik eller mere praksisnærhed. Der bliver nødt til at være en vis afstand til praksis (Fink, 2019, s. 11). Sociolog Jørn Bjerre påpeger ligeledes vigtigheden af distance til praksis. At kunne betragte praksis kræver analytisk distance. Hvis der ikke er den nødvendige distance, reduceres antallet af handlemuligheder. Har man derimod en generel viden, er man åben for alternative handlemuligheder (Bjerre, 2016, s. 38).

\section{Hvorfor har de lærerstuderende og nye lærere svært ved at se teoriens brugbarhed?}

De nye lærere fortæller meget enstemmigt om et job, som er hårdt, men også givende. Arbejdspresset er meget stort, og de bliver overraskede over, hvor mange arbejdsopgaver der er ud over selve undervisningen. Set i det lys er det forståeligt, at de efterspørger konkrete værktøjer, der kan bruges direkte i en presset hverdag. De står i en situation med akut handletvang (Hovdenak \& Wiese, 2017, s. 179). Som det er fremgået, er det en udfordring for en del lærerstuderende - og også mange af de nye lærere - at anvende teori eller se nytten af teori. Udover den handletvang, de står i, er der også andre grunde til, at de kan have svært ved at se brugbarheden af teori. Teori er lig med en analytisk distance, og netop den distance kan være vanskelig for praktikeren, der står i situationer, der fordrer det modsatte, nemlig nærvær og empati (Andersen, 2020, s. 63). En undersøgelse af lærerstuderende i Norge peger på samme problem angående de studerendes optagethed af værktøjer. De norske lærerstuderende er meget lidt optaget af den kundskabsform, der understøtter kritisk og refleksiv tænkning (Hovdenak \& Wiese, 2017). De studerendes og nye læreres manglende optagethed af teoretisk viden modsiges af nogle af de ambitioner, som man kan finde i både dansk og europæisk sammenhæng, hvor idealet er læreren som en fagperson, der både kan undersøge, analysere og udvikle praksis. Det fremgår fx af Common European Principles for Teacher Competences and Qualifications, hvor det fremhæves, at lærerne spiller en afgørende rolle i videnssamfundet. Det hedder bl.a.: "Their education and professional development should equip them to access, analyse, validate, reflect on and transmit knowledge (Common European Principles for Teacher Competences and Qualifications, 2010). Vi møder det fx også i rapporten Udvikling af læreruddannelsen. Retning, indhold, principper og progression i fremtidens læreruddannelse fra 2020, som er Danske Professi- 
onshøjskolers bud på en fremtidig læreruddannelse. Her er idealet en lærer, der er i stand til at reflektere over og undersøge praksis og kunne tilegne sig ny teori (Danske Professionshøjskoler, 2020, s. 8).

Peter Østergaard Andersen peger på en central forskel på det akademiske felt og det praktiske felt. Det akademiske felt retter sig mod sandhed, det praktiske felt mod brugbarhed. Derfor kan den akademiske viden virke forstyrrende ind i en travl hverdag. Andersen peger på, at den akademiske viden har til opgave at vise, at "tingene ikke altid er, som de tager sig ud" (Andersen, 2020). Det praktiske felt retter sig som nævnt mod brugbarhed, og derfor er det forståeligt nok den form for viden, de nyuddannede lærere efterspørger og oplever, at de har brug for, når hverdagen er presset. Teorierne skal ifølge hovedparten af de nye lærere være "brugbare" for at være attraktive. Det er de i sagens natur ikke nødvendigvis. Desuden er det ikke teoriens rolle at levere "her-og-nu-løsninger", men bl.a. at give analytisk distance til egen praksis, som tidligere nævnt.

Siden læreruddannelsesreformen i 2013 har der været to dominerende diskurser i læreruddannelsen: et ønske om en større forskningsforankring og et ønske om en større praksisforankring (fx Carlsen \& von Oettingen, 2020). Disse to diskurser går ikke altid lige godt i spænd. Ovenfor er der refereret til en norsk undersøgelse, der viser, at de lærerstuderende i høj grad er styret af en "værktøjskassetænkning", der kan hindre en kritisk refleksion. En anden undersøgelse fra Norge peger imidlertid på positive resultater i forhold til at få nye lærere til at anvende forskningsbaseret viden i jobbet som lærere og på den måde medvirke til skoleudvikling (Bjørndal et al., 2020). I forbindelse med udviklingen af den femårige læreruddannelse har man arbejdet systematisk med at bibringe norske lærerstuderende forsknings- og udviklingskompetencer med henblik på at kunne udvikle egen praksis som lærer og med henblik på at styrke de nye læreres professionskundskab (Bjørndal et al., 2020, s. 3). Ved at opbygge forskningskompetencer skal de studerende lære at blive "undersøgende praktikere". De nye lærere i den norske undersøgelse peger blandt andet på, at de bruger deres forsknings- og udviklingskompetence i forhold til deres undervisningspraksis og klasseledelse (Bjørndal et al., 2020, s. 11). De positive resultater til trods er der i undersøgelsen også lærere, der peger på, at det på grund af mangel på tid var vanskeligt at anvende forsknings- og udviklingskompetencen. De havde travlt med $\mathrm{fx}$ at skabe ro i klassen og samarbejde med forældrene (Bjørndal et al., 2020, s. 14). En anden faktor, der modarbejdede brugen af de nye læreres forsknings- og udviklingskompetence, er skolens organisering samt 
manglende interesse og opmærksomhed fra skolen (Bjørndal et al., 2020, s. 16). Dorthe Carlsen og Alexander von Oettingen nævner også, at det kræver noget af skolens organisering og fra skolens ledelse, hvis man skal inddrage lærere og lærerstuderendes forskning- og udviklingsarbejde i folkeskolen (Carlsen \& von Oettingen, 2020, s. 15). De lærerstuderende og nye lærere efterspørger, som det er fremgået, ofte et "en-til-en-forhold" mellem teori og praksis. Problemet er imidlertid, at teori netop ikke handler om det konkrete, men om det almene. Den kan i sagens natur ikke anvendes direkte. von Oettingen formulerer forholdet mellem teori og praksis således:
"På den ene side er teorien afskåret fra at give et fuldstændigt billede af praksis, fordi den $i$ sin almenhed ikke kan fange det særlige. Derfor kan der ikke bestå en kausal sammenhæng mellem teoretiske definitio- ner og deres praktiske implementering. På den anden side kan praksis ikke undvære teorien, da praktikeren dels ville blive hængende i sin erfaringskreds, dels slet ikke tage ved lære af praksis." (von Oettingen, 2006, s. 299)

I forhold til tanken om teoriens anvendelighed er det også vigtigt at skelne mellem kortsigtet og langsigtet nytte. Teoriudvikling er ofte lig langsigtet nytte (Fink, 2019, s. 11; Andersen, 2020, s. 68).

En enkelt af de nye lærere i vores undersøgelse giver udtryk for, at den analytiske dimension måske først kommer med tiden. Vedkommende formulerer det således:

\footnotetext{
"Hvordan fär man plads til at kunne bruge sin hjerne og behandle en situation på stedet, når man har så mange forskellige ting $i$ hovedet, som skal huskes. Rutinerede lærere gør nogle af tingene pr. automatik, men det gør man ikke som ny lærer. Derfor har man uendeligt lidt overskud og ingen hjernekapacitet til at agere kompetent. Derfor kan man $i$ starten ikke bruge særlig meget af alt det, man har lært på uddannelsen. Jeg håber, der bliver mere og mere overskud til at kigge analytisk på situationer, man står $i$. Udadreagerende elever og uro $i$ klassen har også været meget udfordrende." (Ny lærer 2020)
} 


\section{Afsluttende diskussion og perspektivering}

Som det er fremgået, er der flere grunde til, at nogle lærerstuderende og nye lærere kan have svært ved at se, hvad de skal med læreruddannelsen, og i stedet drages mod skolens "virkelighed" som den arena, hvor man lærer at blive lærer. Det handler for det første om læreridentiteten og familiariteten med professionen, for det andet om udfordringen med læreruddannelsens teoretiske del og for det tredje om en bestemt virkelighedsforståelse. Virkeligheden forstår de som den, der findes "ude" på skolerne, og læreruddannelsen er virkelighedsfjern. I forhold til læreridentiteten og familiariteten med professionen er der fordele og ulemper. Forestillingen om "den gode lærer", der vil "gøre en forskel", er en stærk motivation hos de studerende. Det er også en vigtig motivation, for lærerprofessionen karakteriseres gerne som en profession, der har en særlig moralsk forpligtelse ( $\mathrm{fx}$ Heikkinen et al., 2011, s. 93). De studerende abonnerer således på et professionsideal, der handler om at sætte hensynet til borgeren højere end fx egen vinding, helt i tråd med de såkaldt harmoniske professionsforståelser baseret på Talcott Parson (Parson, 1939). Viljen og lysten til at påtage sig et ansvar og en forpligtelse fejler således intet. På den baggrund kan man sige, at de studerende allerede inden læreruddannelsen har indstillet sig på at være en professionel. Men det er ikke nok at ville noget for at være professionel, man skal også kunne noget, og denne kunnen kan man ikke udelukkende erfare sig til. En profession er nemlig også karakteriseret ved en specifik og afgrænset viden og et professionssprog, der adskiller sig fra et hverdagssprog ( $f x$ Afdal, 2012; Nielsen, 2014; Jacobsen \& Komischke-Konnerup, 2019). Som vi tidligere har været inde på, understreger von Oettingen, at medlemskab af en profession indebærer, at man oparbejder en særlig viden, der ikke alene er praktisk, men også teoretisk. Argumentet er, at det netop kræver teoretisk refleksion at kunne navigere og tage stilling i en kompleks praksis. Imidlertid efterspørger både de studerende og de nye lærere i høj grad konkrete redskaber og værktøjer, der kan bruges direkte - og uden for meget refleksion. Spørgsmålet er, om det er læreruddannelsens opgave at gøre lærerstuderende i stand til at bruge konkrete redskaber. Er det læreruddannelsens opgave at træne de studerende $i$ at skrive elevplaner og bruge Aula? Er det læreruddannelsens opgave at lære de studerende at gå på kompromis, fordi vi ved, at det bliver de nødt til, når de kommer ud på folkeskolerne? Eller er det snarere læreruddannelsens opgave at gøre de studerende i stand til kritisk at kunne reflektere over værktøjer, vilkår og kvalitetskriterier, gen- 
nemskue, hvilke børnesyn og pædagogikker de hviler på, og dernæst tage stilling til, hvordan de vil forholde sig til dem i deres lærerpraksis og i det konkrete samspil med børn og forældre? Hvis læreruddannelsen alene blev en uddannelse $i$ at anvende konkrete redskaber i den aktuelle folkeskolevirkelighed, ville den paradoksalt nok samtidig være med til at afprofessionalisere lærergerningen.

Det bringer os videre til det tredje punkt, som handler om de studerendes syn på "virkeligheden". Som fremgået er mange af de studerende meget optagede af at blive så klar som muligt til "virkeligheden", som de vel at mærke mener er at finde ude på skolerne. De politiske ambitioner for læreruddannelsen er formuleret i lignende vendinger. Det er interessant nok den virkelighedsforståelse, vi møder i pressemeddelelsen fra Forsknings- og Uddannelsesministeriet, når det hedder, at de lærerstuderende "skal klædes bedre på til at træde ud i virkeligheden" (Uddannelses- og Forskningsministeriet, 2020). Men som fremgået indebærer det at træde ud i "virkeligheden" også en stor udfordring i forhold til de studerendes identitetsarbejde. Hvor de studerende gennem uddannelsen har kunnet holde de organisatoriske forhold ud i strakt arm, ser det anderledes ud, når de kommer ud på skolerne. Her bliver en del af dem så udfordrede af at måtte gentænke deres læreridentitet, at de bliver sygemeldt med stress eller helt opgiver lærerjobbet, når de erkender, at det på grund af de organisatoriske forhold at vanskeligt at gøre en positiv forskel i børnenes liv. Spørgsmålet er, om man vil forsøge at få de lærerstuderendes drømme og læreruddannelsens teorier om pædagogik og didaktik til at indrette sig efter "virkeligheden" eller omvendt? Hvad nu, hvis "virkeligheden" ude på skolerne er problemfyldt? Skal de nyuddannede lærere så stadig blot "træde ind i den", som den er? I forlængelse af den diskussion er det interessant at bemærke, at der er en diskrepans mellem de lærerstuderende og de nye lærere. Som det er fremgået, er motivationen hos de lærerstuderende ofte en lærer, de selv har haft, som de synes har været eksemplarisk. Imidlertid tager de under uddannelsen afstand fra de "gamle brokkehoveder", der i sagens natur netop kunne være den "eksemplariske lærer", der fik dem ind på uddannelsen. Når er de færdiguddannede og står som nye lærere, efterspørger de imidlertid, at man godt kunne have fortalt dem, hvor svært det er at realisere idealerne om den gode lærer, og de fremhæver mange af de samme kritikpunkter, som de såkaldte "brokkehoveder".

Kravet om mere praktik er stort, men hvis svaret ikke blot er mere praktik i læreruddannelsen, hvad er svaret så? Hvis vi i første omgang retter blikket mod praktikkens rolle i læreruddannelsen, vil vores bud i stedet være 
bedre praktik og ikke mindst bedre samspil mellem uddannelsens praktiske og teoretiske elementer. Undersøgelser peger - ikke overraskende - på, at praktikperiodens kvalitet har betydning for, om den lærerstuderende oplever at være klædt på til lærerjobbet (Slottved et al., 2019, s. 14). Der er også undersøgelser, der peger på, at en integreret pædagogik i arbejdet med praktikken kan give gode resultater, hvor man netop styrker lærernes professionelle autonomi. Det kræver både en praktisk og en teoretisk viden (Heikkinen et al., 2011). At kvalificere praktikken er en krævende opgave, der fordrer en stor indsats fra både læreruddannelsens og kommunernes side. Det vil også kræve mere forskning i praktik, som er det et felt, der desværre er præget af vilkårlighed (Mattsson, 2011, s. 10). Ikke bare i Danmark, men også internationalt er der et ønske om en læreruddannelse, der både har en forskningsforankring og en praksisforankring (fx Carlsen \& von Oettingen, 2020; Heikkinen et al., 2011). Der er, som fremgået, et ønske om, at lærerstuderende skal kunne indgå i eller stifte bekendtskab med forskning- og udviklingsarbejde. Hvis man udelukkende honorerer de studerendes og de nye læreres ønske, er der en risiko for, at der opstår et entydigt fokus på praksisforankringen. Den store udfordring for læreruddannelsen lige nu er at undgå en polarisering mellem forskningsforankring og praksisforankring. Der er et behov for bedre uddannelse af både praktiklærere og læreruddannere. Undersøgelser peger på, at praktiklærerne i høj grad ser sig selv primært som lærere for eleverne og ikke som læreruddannere, hvad de ret beset er i samarbejdet om praktikken (fx Paaske et al., 2016, s. 70-75; Kunnskapsdepartementet, 2017). Igen er det formentlig fordi motivationen og læreridealet spiller så stor en rolle, som de gør. Som læreruddanner står man med, hvad man kalder det dobbelte teori/praksisproblem eller andenordensdidaktik (Iskov, 2020; von Oettingen \& Jensen, 2017). Det betyder, at man skal praktisere det, man teoretisk formidler. Man skal kunne forholde sig kritisk refleksivt til egne didaktiske valg, samtidig med at man faktisk gør det, man siger, der skal gøres, pointerer Elsebeth Jensen og Alexander von Oettingen (von Oettingen \& Jensen, 2017, s. 30). Det er en udfordrende situation, der fx kan kvalificeres gennem lektorkvalificeringsprocessen.

Hvis "virkeligheden" ude på skolerne er uhensigtsmæssig for både elever og lærere, og de organisatoriske rammer gør, at det er svært at få den fornødne tid til at drage omsorg for eleverne, både fagligt og socialt, skal lærerne i så fald tilpasse sig? De blev lærere, fordi de vil gøre en positiv forskel i børns liv ved at bidrage til deres udvikling som samfundsborgere. Det fordrer, at man ikke bare træder ud i virkeligheden, men at man også 
er i stand til at ændre den og udvikle den. Det fordrer, at man abonnerer på begge sider af professionsidealet, dvs. både viljen til at forpligte sig, men også at kunne, hvilket fordrer en teoretisk viden og et professionelt fagsprog. Det er ikke tilstrækkeligt kun at gøre sig praksisnære erfaringer. Hvis det var tilfældet, kunne vi helt droppe læreruddannelsen.

Hvis vi vil have en skole, hvor de professionelle kan omsætte deres lyst til at gøre en positiv forskel for børn og unge, kræver det en indsats fra såvel læreruddannelsen som folkeskolen. Både læreruddannelsen og folkeskolen skal i løbet af de næste år blive bedre til i samarbejde at skabe balance og koblinger mellem forskningsforankring og praksisforankring. Det fordrer praksisnærhed og praksisfjernhed begge steder. Indledningsvist stillede vi spørgsmålet: Hvad skal vi med læreruddannelsen? I skrivende stund arbejder man med justeringer af uddannelsen. Pilen peger i retning af en "styrket" praktik og et "styrket" praksisarbejde. En sådan styrkelse er i sig selv udmærket og nødvendig; men den kan ikke stå alene. Læreruddannelsen skal også blive bedre til at vække de studerendes vidensbegær og lyst til kritisk refleksion. At ville imitere den gode lærer, man selv har haft, er ikke et tilstrækkeligt grundlag for at kunne "gøre en forskel" for eleverne. Det er heller ikke nødvendigvis en fordel, at uddannelsen - eller praktikken - forsøger at ligne folkeskolen. Man klæder ikke de studerende tilstrækkeligt på til lærergerningen alene gennem en styrket praktik. Måske skal man i stedet tale om et styrket teori/praksis-forhold. De studerende har brug for en læreruddannelse, der ikke giver efter for politisk pres ved at sænke barren, og som tillader sig selv også at være virkelighedsfjern for at kunne praktisere idealet om den gode lærer - for elevernes og folkeskolens skyld.

\section{Referencer}

Afdal, H. W. (2011). Knowledge in teacher education curricula: examining differences between a research-based program and a general professional program. Nordic Studies in Education, 32, 245-261.

Andersen, P. Ø. (2020). Forestillinger om anvendelse inden for professionsfeltet - og om mulige metodologiske konsekvenser. Tidsskrift for professionsstudier, 30(1), 62-71.

Bayer, M. (2017). Person, Pædagogik, profession og forskning. Hans Reitzels Forlag.

Bjerre, J. (2016). Refleksiv praksislæring mellem mesterlære og formel uddannelse. CEPRA-Striben, (20), 36-41.

Bjørndal, K. E. W., Antonsen, Y., \& Jakhelln, R. (2020). FoU-kompetansen til nyutdannede grunnskolelærere - grunnlag for skoleutvikling? Acta Didactica Norden, 14(2). http:// dx.doi.org/10.5617/adno.7917

Böwadt, P. R., Pedersen, R., \& Vaaben, N. (2017). "Først og fremmest elsker jeg at arbejde med børn" - om studerendes valg af lærerlivet. Professionshøjskolen UCC. 
Böwadt, P. R., Pedersen, R., \& Vaaben, N. (2019a). Når verdens bedste job bliver for hårdt - en undersøgelse af, hoordan lærere har det i folkeskolen. Københavns Professionshøjskole.

Böwadt, P. R., Pedersen, R., \& Vaaben, N. (2019b). På tærsklen til at blive lærer - Studerendes overvejelser om deres kommende arbejdsliv. Københavns Professionshøjskole.

Böwadt, P. R., Pedersen, R., \& Vaaben, N. (2020). Lærere mellem engagement og afmagt. Forskning til skolen. Forlaget UP - Unge Pædagoger.

Böwadt, P. R., Pedersen, R. \& Vaaben, N. (2021). Personlig tilblivelse på professionsuddannelserne mellem professionsidealer og selvansvarliggørelse. I: Dahl, K. K. B. (red.), Professionspsykologi (s. 327-348). Aarhus Universitetsforlag.

Carlsen, D., \& von Oettingen, A. (2020). Universitetsskolen - et bud på en didaktisk orienteret forskningsbasering af læreruddannelsen. Acta Didactica Norden, 14(2). http:// dx.doi.org/10.5617/adno.7912

Common European Principles for Teacher Competences and Qualifications 2010.

Dorf, H. (2018). Skolepolitik og uddannelseskvalitet i Danmark. Aarhus Universitetsforlag.

Dahl, K. K. B. (2020). Mo(ve)ments in professional identification: achieving professional identity and becoming a teacher in Danish and Kenyan teacher education. Compare: $A$ Journal of Comparativ and International Education, 50(1), 123-140.

Danske Professionshøjskoler (2020). Udvikling af læreruddannelsen. Retning, indhold, principper og progression i fremtidens læreruddannelse.

Driver, M. (2009). From Loss to Lack: Stories of Organizational Change as Encounters with Failed Fantasies of Self, Work and Organization. Organization, 16(3), 353-369. https://doi.org/10.1177/1350508409102300

Ekspertgruppen (2018). Kvalitet og relevans i læreruddannelsen. Ekspertgruppens evaluering og vurdering af læreruddannelsen af 2013. Styrelsen for Forskning og Uddannelse.

Fink, H. (2019). Om teori og praksis, nærhed og fjernhed. Tidsskrift for Professionsstudier, 29, 6-13.

Heikkinen, H. L. T., Tynjälä, P., \& Kiviniemi, U. (2011). Integrative pedagogy in practicum. Meeting the Second Order Paradox of Teacher Education. I: Mattsson, M., Eilertsen, T. V., \& Rorrison, D.(red.), A Practicum Turn in Teacher Education (s. 91-112). Sense Publishers.

Hovdenak, S. S., \& Wiese, E. (2017). Fronesis: vejen til profesjonell lærerutdanning. Uniped, 40(2), 170-184. https://doi.org/10.18261/ISSN.1893-8981-2017-02-06

Humle, D. M., \& Frandsen, S. (2017). Organizational identity negotiations through dominant and counternarratives. I: Frandsen, S., Kuhn, T., \& Lundholt, M. W. (red.), Counter-Narratives and Organization (s. 105-128). Routledge.

Humle, D. M. (2014). Remembering who WE are: memories of identity through storytelling. Tamara, Journal of critical organizational inquiry, 12(2), 11-24.

Iskov, T. (2020). Læreruddannelsens andenordensdidaktik. Studier i læreruddannelse og -profession 5(1), 92-114.

Jacobsen, B. (1989). Fungerer læreruddannelsen? Undervisningsministeriet.

Jacobsen, G. H., \& Komischke-Konnerup, L. (2019). Pædagogisk professionssprog: Hvor blev det af, og hvordan kan det genopdages og videreudvikles? Tidsskrift for Professionsstudier, 15(28), 46-58.

Johansen, M. B. (2017). Teori og praksis i professioner og professionsuddannelser. I: Andersen, P. Ø., \& Ellegaard, T. (red.), Klassisk og moderne pædagogisk teori (s. 244-254). Hans Reitzels Forlag.

Jorgensen, E. R. (2005). Four Philosophical Models of the Relationship Between Theory and Practice. Philosophy of Music Education Review, 13(1), 21-36.

Krarup, M. (2017). Frafald og fastholdelse på de danske læreruddannelser. Unge pædagoger, 2, 7-19. 
Kunnskapsdepartementet (2017). Lærerutdanning 2025. Nasjonal strategi for kvalitet og samarbeid i lærerutdanningene.

Lindhart, L. (2007). Hvor lærer en lærer at være lærer? Books on demand.

Mattsson, M., Eilertsen, T. V., \& Rorrison, D. (2011). What is practice in teacher education? I: Mattsson, M., Eilertsen, T. V., \& Rorrison, D. (red.), A Practical Turn in Teacher Education (s. 1-15). Sense Publishers.

Mintrop, R., \& Ordenes, M. (2017). Teacher work motivation in the era of extrinsic incentives: Performance goals and pro-social commitments in the service of equity. Education Policy Analysis Archives, 25(44). 10.14507/epaa.25.2482

Moos, L. (2011). Engagement og afmagt i lærer- og skolelederarbejdet. I: Bovbjerg, K. (red.), Motivation og mismod: Effektiviseringer og stress på offentlige arbejdspladser (s. 183209). Aarhus Universitetsforlag.

Nielsen, T. K. (2014). Teori og praksis i professionsbacheloruddannelserne. Et systematisk review. Aarhus Universitet. Ph.d.-afhandling.

Paaske, K. A., Frederiksen, L. L., \& Mølgaard, D. B. (2017). En metasyntese af vejledning i læreruddannelser i Norden. Studier i læreruddannelse og -profession, 2(2), 62-83.

Parsons, T. (1939). Professions and social structure. Social forces, 17(4), 457-467. https://doi. org/10.2307/2570695

Pedersen, R., Böwadt, P. R., \& Vaaben, N. (2016). Hvorfor stopper lærerne i folkeskolen? Professionshøjskolen UCC.

Rose, N. (1999). Governing the Soul. The Shaping of the Private Self. Free Association Books.

Slottved, M., Foged, S. K., \& Nøhr, K. (2019). Lxreruddannelsen i et internationalt perspektiv En litteraturkortlægning. VIVE.

Uddannelses- og Forskningsministeriet (27. nov 2020). Nytænkning af Læreruddannelsen - et ambitiøst udviklingsarbejde. Ref.nr 2020 - 4912.

Vaaben, N., \& Bjerg, H. (2019). The Danish school as a haunted house: reforming time, work life and fantasies of teaching in Denmark. Ephemera: Theory and politics in organization, 19(1), 107-128.

Vidø, S., \& Marcussen, J. (2002). Det gode lærerliv. Mercuri Urval for Danmarks Lærerforening.

von Oettingen, A. (2006). Pædagogisk filosofi som reflekteret omgang med pædagogiske antinomier: perspektivering af K. Grue Sørensens filosofiske pædagogik. Forlaget Klim.

von Oettingen, A. (2007). Pædagogiske handlingsteorier i differencen mellem teori og praksis. I: von Oettingen, A., \& Weidemann, F. (red.), Mellem teori og praksis: Aktuelle udfordringer for pædagogiske professioner og professionsuddannelser (s. 17-52). Syddansk Universitetsforlag.

von Oettingen, A., \& Jensen, E. (2017). Hvad skal en læreruddanner vide og kunne for at uddanne lærere? Paideia, 13, 27-39.

Willig, R. (2013). Kritikkens U-vending. Hans Reitzels Forlag. 